\title{
HRK wt Allele
}

National Cancer Institute

\section{Source}

National Cancer Institute. HRK wt Allele. NCI Thesaurus. Code C49422.

Human HRK wild-type allele is located in the vicinity of 12 q24.23 and is less than $1 \mathrm{~kb}$ in length. This allele, which encodes activator of apoptosis harakiri protein, is involved in the regulation of apoptosis. 